\title{
ANALISIS PERBANDINGAN PENDAPATAN BURUH HARIAN TETAP DENGAN BURUH HARIAN LEPAS DAN PENGARUHNYA TERHADAP KESEJAHTERAAN KELUARGA BURUH PERKEBUNAN KELAPA SAWIT DI KOTA SUBULUSSALAM
}

\author{
Khairil Anwar ${ }^{\mathrm{a}^{*}}$, Heri Setiawan ${ }^{\mathrm{a}^{*}}$ \\ ${ }^{a}$ Fakultas Ekonomi dan Bisnis Universitas Malikussaleh \\ *Corresponding author: khairilanwar@unimal.ac.id \\ * heriadrt910@gmail.com
}

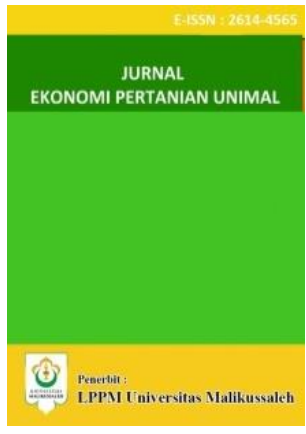

ARTICLE INFORMATION

A B S T RA C T

Keywords:Permanent Daily Workers' Income, Daily Workers, Family Welfare

\begin{abstract}
This study aims to determine and analyze the level of differences in income and the level of welfare of day laborers in oil palm plantations in the city of subulussalam. This study uses a comparative method and quantitative methods with 2SLS. The sample in this study is 50 permanent daily workers and 50 daily workers. The results of thisstudy indicate that there are differences in income and the level of welfare of permanent workers, where the welfare level of the daily labor remains more prosperous then the permanent workers. The factors that most influence the level of welfare of permanent labor is that the level of income of daily laborers is still greater than the income of permanent laborers.
\end{abstract}

\section{PENDAHULUAN}

Pembangunan ekonomi merupakan usaha dan kebijakan yang di tetapkan pemerintah dengan tujuan akhir untuk meningkatkan taraf hidup masyarakat, memperbanyak lapangan pekerjaan dan memeratakan pendapatan masyarakat. Dengan istilah lain, arah pembangunan ekonomi mengupayakan agar pendapatan masyarakat dapat meningkat dengan tingkat pemerataan yang sebaik mungkin sehingga tercapainya kesejahteraan (Puspitawati, 2013).

Mensejahterakan masyarakat adalah tujuan utama negara berkembang, tingkat kesejahteraan masyarakat serta merta menjadi salah satu indikator dalam menilai keberhasilan pembangunan ekonomi. Pola konsumsi keluarga mencerminkan seberapa besar tingkat kesejahteraan keluarga tersebut, terutama bidang perekonomian yang mengakibatkan terjadinya perbedaan pola konsumsi antar masyarakat secara umum dan tingkat keluarga secara khusus. Perbedaan kuantitas dan kualitas konsumsi antar keluarga di karenakan berbedanya pendapatan keluarga, jumlah anggota keluarga, jabatan anggota keluarga dan kebutuhan rumah tangga.

Konsep kesejahteraan sangat erat kaitannya dengan konsep kebutuhan, dengan terpenuhinya kebutuhan, maka seseorang sudah dapat dikatakan sejahtera. Karena tingkat kebutuhan seseorang secara tidak langsung sejalan dengan indikator kesejahteraan. Teori Maslow mengambarkan rumusan tentang kebutuhan yang hirarki dalam bentuk segitiga, dimana kebutuhan yang ada di atas akan terpenuhi setelah kebutuhan di bawahnya terpenuhi. Tingkat paling bawah dalam susunan kebutuhan tersebut adalah kebutuhan fisik yang menyangkut kebutuhan pokok seperti pangan, sandang dan papan. Kemudian dilanjutkan kebutuhan akan rasa aman, kebutuhan sosial dan kebutuhan penghargaan atas diri sendiri (Nitisusastro, 2013).

Perkebunan memiliki fungsi ekonomi, yang dapat meningkatkan kemakmuran serta kesejahteraan masyarakat secara keseluruhan dan penguatan struktur ekonomi regional dan nasional. Menjadi salah satu faktor pendukung untuk mempercepat kemajuan di bidang pertanian, sektor perkebunan di integrasikan kedalam sektor pertanian.

Tabel 1

Jumlah Penduduk Yang Berkerja Di Sektor Perkebunan, IndustriDan Jasa-Jasa Di Kota Subulussalam 2016 


\begin{tabular}{|l|c|c|c|c|}
\hline \multirow{2}{*}{$\begin{array}{l}\text { N } \\
\text { o }\end{array}$} & \multirow{2}{*}{ Sektor } & \multicolumn{3}{|c|}{ Jumlah Pekerja } \\
\cline { 3 - 5 } & & Laki-Laki & Perempuan & Jumlah \\
\hline 1 & Perkebunan & $\mathbf{9 . 4 5 2}$ & 4.654 & 14.106 \\
\hline 2 & Industri & $\mathbf{1 . 6 4 1}$ & 139 & 1.780 \\
\hline 3 & Jasa-jasa & $\mathbf{6 . 1 0 6}$ & 4.767 & 10.873 \\
\hline & Jumlah & $\mathbf{1 7 . 1 9 9}$ & 9.560 & $\mathbf{2 6 . 7 5 9}$ \\
\hline
\end{tabular}

Sumber : BPS Kota Subulussalam, 2016

Dari tabel 1 di atas, di ketahui bahwa sektor perkebunan menjadi sektor yang paling banyak menyerap tenaga kerja dengan berjumlah 14.106 orang dengan rincian 9.452 laki-laki dan 4.654 perempuan. Sektor jasa-jasa menjadi sektor kedua terbanyak menyerap tenaga kerja yaitu sebanyak 10.873 dengan rincian 6.106 laki-laki dan 4.767 perempuan. Sektor industri menjadi sektor paling sedikit menyerap tenaga kerja dibandingkan dengan kedua sektor lain di atas di mana sektor industri menyerap tenaga kerja sebanyak 1.780 orang tenaga kerja dengan rincian 1.641 orang laki-laki dan 139 orang perempuan.

Seiring dengan pergeseran serta peningkatan pendapatan, jumlah pengeluaran untuk pangan akan menurun dan meningkatnya jumlah pengeluaran untuk kebutuhan nonpangan. Darikomoditiyang dikonsumsi keluarga akan mempunyai kepuasan tersendiri. Dalam kegiatan konsumsi setiap keluarga memilikijenispengeluaranyang berbeda. Perbedaan pola konsumsi pada setiap keluarga dijadikan sebagai beban atau tanggungan dalam memenuhi kebutuhan semua anggota keluarga, sehingga dijadikan sebagai ukuran tercapainya kesejahteraan keluarga secara merat adan utuh.

Kesejahteraan pada hakekatnya terpenuhinya segala kebutuhan anggota keluarga dengan melakukan kegiatan konsumsi, yang dipenuhi dengan pendapatan yang dimiliki hingga mencapai kesejahteraan.

Berdasarkan hasil uraian latar belakang di atas, maka peneliti tertarik untuk meneliti masalah ini dengan judul "Analisis Perbandingan Pendapatan Buruh Harian Tetap Dengan Buruh Harian Lepas Dan Pengaruhnya Terhadap Kesejahteraan Keluarga Buruh Perkebunan Kelapa Sawit Di Kota Subulussalam".

\section{LANDASAN TEORITIS}

\section{KesejahteraanKeluarga}

Pengertian kesejahteraan menurut KBBI

(Kamus Besar Bahasa Indonesia), kata kesejahteraan berasal dari kata sejahtera yang mempunyai makna aman, makmur, dan sentosa (terlepas dari gangguan, kesukaran, dan sebagainya). Kata sejahtera memiliki pengertian dari bahasa sanskerta "catera" yang berati payung. Catera dalam konteks kesejahteraan berarti orang yang sejahtera, yakni orang yang dalam hidupnya bebas dari kemiskinan, kebodohan, ketakutan, atau kekhawatiran sehingga hidup aman dan tentram, baik lahir maupun batin (Purwana, 2014).

Kesejahteraan menurut (Nurachmad, 2009) adalah suatu pemenuhan kebutuhan atau keperluan yang bersifat jasmaniah dan rohaniah, baik di dalam maupun diluar hubungan kerja.

Secara keseluruhan kesejahteraan sangat beragam. Menurut undang-undang No. 52 Tahun 2009 menyatakan bahwa keluarga yang sejahtera adalah keluarga yang berdasarkan perkawinan yang sah, mampu memenuhi kebutuhan hidup lahir dan bathin, bertakwa kepada Tuhan YME serta memiliki hubungan serasi, selaras serta seimbang antara anggota keluarga dan antar keluarga dengan masyarakat lain dan lingkungan.

\section{Pendapatan}

Dalam KBBI (kamus besar bahasa Indonesia), pendapatan adalah hasil kerja (usahadan sebagainya). Sedangkan pendapatan menurut kamus manajemen adalah jumlah uang yang diterima oleh seseorang, perusahaan, dan organisasi lain dalam bentuk upah, gaji, sewa, bunga, komisi, dan laba (Marbum, 2003).

Sukirno mendefinisikan pendapatan adalah jumlah penghasilan yang diterima oleh penduduk atas prestasi kerjanya selama satu periode tertentu, baik harian, mingguan, bulanan, ataupun tahunan. (Sukirno, 2006)

Menurut

(Reksoprayitno,

Pendapatan adalah jumlah pendapatan yang diterima oleh para anggota masyarakat untuk jangka waktu tertentu sebagai balas jasa atas faktor-faktor produksi yang mereka sumbangkan dan turut serta membentuk produk nasional. Menurut Reksoprayitno, pendapatan atau income adalah uang yang diterima oleh seseorang dan perusahaan dalam bentuk gaji, upah, sewa bunga, dan laba termasuk juga beragam tunjangan, seperti kesehatan dan pensiun.

\section{METODE PENELITIAN}

Penentuan jumlah sampel digunakan pendekatan Slovin dengan perhitungan sebagai berikut:

Dimana:

$$
n=\frac{N}{1+N e^{2}}
$$

$$
\mathrm{n} \quad=\text { Sampel }
$$




$$
\begin{array}{ll}
\mathrm{N} & =\text { Populasi } \\
\mathrm{e} & =\text { Persentase } \\
1 & =\text { Konstanta }
\end{array}
$$

Dengan jumlah populasi sebesar 14.106 buruh harian dan presisi sebesar 0,10 (10\%), maka jumlah sampel minimal adalah:

$$
\begin{aligned}
& n=\frac{14.106}{1+} 14.106(0,10)^{2} \\
&=99,59(\text { dibulatkan menjadi }
\end{aligned}
$$$$
100 \text { buruh harian) }
$$

Dengan demikian jumlah sampel yang diambil dalam penelitian ini adalah sebanyak 100 orang buruh. Di mana buruh harian tetap (BHT) berjumlah 50 orang dan buruh harian lepas (BHL) berjumlah 50 orang.

\section{Definisi Operasional Variabel}

1. Kesejahteraan Keluarga Buruh (Y) Besarnya pengeluaran untuk memenuhi kebutuhan rumah tangga. Indikatornya adalah pengeluaran untuk konsumsi, pengeluaran untuk pendidikan dan pengeluaran untuk kesehatan (Satuan Rp.)

2. Pendapatan Buruh Harian Tetap (X1) Jumlah penghasilan yang diterima oleh buruh harian tetap atas prestasi kerjanya selama satu periode tertentu.

Indikatornya adalah upah, bonus dan insentif (Satuan Rp)

3. Buruh Harian Lepas (X2)

Jumlah penghasilan yang diterima oleh buruh harian tetap atas prestasi kerjanya selama satu periode tertentu.

Indikatornya adalah upah dan bonus (Satuan Rp).

\section{Metode Analisis Data}

Metode analisis data yang digunakan dalam penelitian ini adalah metode perbandingan dan kuantitatif yaitu penelitian yang dimaksudkan untuk mencari kebenaran dari hipotesis sementara yang telah dibuat sebelumnya. Untuk melihat perbedaan pendapatan buruh harian tetap dan buruh harian lepas digunakan model uji beda Independent sample t-test atau uji $\mathrm{t}$ sampel independen. Sebelum di lakukan pengujian maka terlebih dahulu dilakukan uji f untuk mengetahui apakah varian sama atau tidak. Rumus uji $\mathrm{F}$ sebagai berikut:

$$
\text { F hitung }=\frac{\text { Varian Terbesar }}{\text { Varian Terkecil }}
$$

Dengan kaidah keputusan:
1.Jika $\mathrm{F}$ hitung $>\mathrm{F}$ tabel $(\alpha=0.05)$ maka varians sama

2. Jika $F$ hitung $<F$ tabel $(\alpha=0.05)$ maka varian tidak sama

Menurut (Sugiyono, 2014), setelah varians di ketahui sama atau tidak melalui uji f. Maka dapat dilakukan pengujian hipotesis dengan menggunakan rumus uji t sebagai berikut:

1. Rumus t hitung untuk varians sama

$$
\mathrm{t}=\frac{\bar{X}_{2}-\bar{X}_{2}}{\sqrt{\frac{\left(n_{1}-1\right) S_{1}^{2}+\left(n_{2}-1\right) S_{2}^{2}}{n_{1}+n_{2}-2}\left(\frac{1}{n_{1}}+\frac{1}{n_{2}}\right)}}
$$

2. Rumus t hitung untuk varian tidak sama

\section{Dimana:}

$$
\begin{aligned}
& t=\frac{x_{1}+x_{2}}{\sqrt{\frac{s_{1}^{2}}{n_{1}}+\frac{s_{2}^{2}}{n_{2}}}} \\
& \text { df }: n_{1}+n_{2}-2
\end{aligned}
$$

$\bar{X}_{1}$ atau $\bar{X}_{2}$ : rata-rata sampel kelompok 1 atau 2

$\mathrm{n}_{1}$ atau $\mathrm{n}_{2} \quad$ : jumlah kelompok 1 atau 2

$\mathrm{S}_{1}$ atau $\mathrm{S}_{2} \quad$ : standar deviasi kelompok 1 atau kelompok 2

df

kebebasan)

Selanjutnya, Untuk mengukur pengaruh atau hubungan pendapatan terhadap kesejahteraan keluarga buruh harian digunakan model regresi linier sederhana dengan metode 2SLS dan bantuan program SPSS. Penggunaan regresi linier sederhana dilakukan berdasarkan asumsi dasar bahwa kesejahteraan keluarga ditentukan oleh variabel exsplanatori yaitu: pendapatan buruh harian tetap (BHT) dan buruh harian lepas (BHL). Adapun formulasi model regresi dalam penelitian ini adalah sebagai berikut:

Dimana:

$$
\begin{aligned}
& Y_{1}=\alpha_{0}+\alpha_{1} X_{1}+e_{1} \\
& Y_{2}=\beta_{0}+\beta_{1} X_{2}+e_{2}
\end{aligned}
$$

$\mathrm{Y}_{1}=$ Kesejahteraan Keluarga Buruh Harian Tetap (BHT)

$\mathrm{Y}_{2}=$ Kesejahteraan Keluarga Buruh Harian Lepas(BHL)

$\alpha_{0}, \beta_{0}=$ Konstanta

$\alpha_{1}, \beta_{1}=$ Koefisien Regresi

$\mathrm{X}_{1} \quad=$ Pendapatan Buruh Harian Tetap (BHT)

$\mathrm{X}_{2} \quad=$ Pendapatan Buruh Harian Lepas (BHL)

$\mathrm{e}_{1}, \mathrm{e}_{2}=$ Error term (Variabel pengganggu) 


\section{HASIL PENELITIAN}

\section{Responden Menurut Pendapatan}

Pendapatan buruh harian merupakan total penerimaan buruh yang diperoleh dari hasil bekerja selama satu bulan. Dalam penelitian ini penulis meneliti pengaruh pendapatan buruh harian tetap dan buruh harian lepas terhadap kesejahteraan keluarga buruh, oleh karena itu sebagai responden penelitian dalam kajian ini adalah mereka yang berprofesi sebagai buruh harian tetap dan buruh harian lepas yang bekerja di perkebunan kelapa sawit di kota subulussalam.

Adapun pendapatan buruh harian per bulan dari hasil bekerja dapat dilihat pada tabel $4.7 \mathrm{di}$ bawah ini :

\section{Tabel 2}

\section{Frekuensi Responden Menurut Pendapatan}

\begin{tabular}{|c|c|c|}
\hline Pendapatan & $\begin{array}{c}\text { Jumlah } \\
\text { Responden }\end{array}$ & Persentase \\
\hline < Rp. 1.000.000 & 0 & $\%$ \\
Rp. 1.000.001 - Rp. 1.500.000 & 22 & $22 \%$ \\
Rp. 1.500.001 - Rp. 2.000.000 & 50 & $50 \%$ \\
Rp. 2.000.001 - Rp. 2.500.000 & 27 & $27 \%$ \\
> Rp. 2.500.001 & 1 & $1 \%$ \\
\hline Jumlah & $\mathbf{1 0 0}$ & $\mathbf{1 0 0 \%}$ \\
\hline
\end{tabular}

Sumber : Hasil kuesioner 2018 (Data Diolah)

Berdasarkan tabel 2 di atas menunjukan bahwa pendapatan buruh harian tetap maupun buruh harian lepas paling rendah yaitu berkisar antara Rp. 1.000 .000 - Rp. 1.500 .000 sebanyak 22 responden (22\%) dan yang menjadi paling dominan yaitu buruh yang berpendapatan berkisar antara Rp. 1.600 .000 - Rp. 2.000.000 sebanyak 50 responden $(50 \%)$. Sedangkan pendapatan buruh yang paling tinggi yaitu sebesar > Rp. 2.600.000. Namun hanya 1 orang responden saja yang berpendapatan tinggi, dengan demikian dapat disimpulkan bahwa mayoritas pendapatan dan tingkat kesejahteraan buruh tergolong rendah dan belum dapat mencukupi kepuasan kebutuhan anggota keluarga.

\section{Responden Menurut Pengeluaran}

Pengeluaran keluarga buruh merupakan total jumlah pengeluaran yang dikelurga anggota keluarga buruh untuk memenuhi kebutuhan konsumsi, kebutuhan pendidikan dan kebutuhan kesehatan. Pengeluran keluarga menjadi indikator yang berpengaruh besar terhadap tingkat kesejahteraan keluarga, dimana besaran pengeluaran akan memperlihatkan seberapa besar kesanggupan suatu keluarga untuk memenuhi konsumsi yang dibutuhkan dalam satu periode.Adapun besaran tingkat pengeluaran keluarga buruh dapat dilihat pada tabel 4.8 di bawah ini:

\section{Tabel 3}

Frekuensi Responden Menurut Pengeluaran

\begin{tabular}{|c|c|c|}
\hline Pengeluaran & $\begin{array}{c}\text { Jumlah } \\
\text { Responden }\end{array}$ & Persentase \\
\hline < Rp. 1.000.000 & 1 & $1 \%$ \\
Rp. 1.000.001 - Rp. 1.500.000 & 59 & $59 \%$ \\
Rp. 1.500.001 - Rp. 2.000.000 & 38 & $38 \%$ \\
Rp. 2.000.001 - Rp. 2.500.000 & 2 & $2 \%$ \\
> Rp. 2.500.001 & 0 & $\%$ \\
\hline Jumlah & $\mathbf{1 0 0}$ & $\mathbf{1 0 0 \%}$ \\
\hline
\end{tabular}

Sumber : Hasil kuesioner 2018 (Data Diolah)

Berdasarkan tabel 3 di atas menunjukan bahwa pengeluaran untuk konsumsi, pendidikan dan kesehatanburuh harian tetap maupun buruh harian lepas paling dominan yaitu berkisar antara Rp.1.000.001 - Rp. 1.500.000 sebanyak 59 responden (59\%). Sedangkan pengeluaran tertinggi buruh harian berkisar antara $\mathrm{Rp}$. 2.000.001 - Rp. 2.500.000 sebanyak 2 responden (2\%) dan pengeluaran terendah berkisar $<\mathrm{Rp}$. 1.000.000 sebanyak 1 responden $(1 \%)$.

\section{Analisis Regresi}

Untuk mengetahui hasil estimasi model penelitian data yang diolah dengan bantuan programSPSS Version 16untuk melihat perbedaan pendapatan buruh harian tetap dan buruh harian lepas serta sejauh mana pengaruh atau hubungan antar variabel bebas (independen) dan variabel terikat (dependen), maka diperoleh hasil perhitungan analisis seperti yang berikut ini:

Tabel 4

Independent Sample T-Test Pendapatan Buruh Harian Tetap Dan Buruh Harian Lepas Di Kota Subulussalam

\begin{tabular}{|c|c|c|c|c|c|}
\hline & pendapatan & $\mathrm{N}$ & Mean & $\begin{array}{c}\text { Std. } \\
\text { Deviation }\end{array}$ & $\begin{array}{l}\text { Std. Error } \\
\text { Mean }\end{array}$ \\
\hline \multirow[t]{2}{*}{ Nilai } & $\begin{array}{l}\text { buruh harian } \\
\text { lepas }\end{array}$ & 50 & 1.6520 & .17640 & .02495 \\
\hline & $\begin{array}{l}\text { buruh harian } \\
\text { tetap }\end{array}$ & 50 & 2.1900 & .24159 & .03417 \\
\hline
\end{tabular}

Dari tabel 4 diatas dapat diketahui bahwa jumlah sampel $(\mathrm{N})$ buruh harian tetap dan buruh harian lepas sama-sama 50 orang. Pendapatan rata-rata buruh harian tetap sebesar 2.1900 (Rp. 2.190.000) dan pendapatan rata-rata buruh harian lepas sebesar 1.6520 (Rp. 1.652.000).

Sebelum dilakukan uji $\mathrm{t}$ test sebelumnya dilakukan uji kesamaan varian (homogenitas) dengan uji $\mathrm{f}$ test (Levene's test). Artinya jika varian sama maka uji t menggunakan Equal Variance Assumed (diasumsikan varian sama) dan 
jika tidak sama maka menggunakan Equal Variance Not Assumed(diasumsikan varian tidak sama. Kriteria pengujian berdasarkan probabilitas/signifikansi, jika $\mathrm{P}$ value $>0.05$ maka variabel sama sedangkan $\mathrm{P}$ value $<0.05$ maka varian tidak sama. Hasil uji $f$ adalah sebagai berikut:

\section{Tabel 5}

\section{Uji Kesamaan Varians (Homogenitas)}

Pendapatan Buruh Harian Tetap Dan Buruh Harian Lepas Di Kota Subulussalam Independent Samples Test

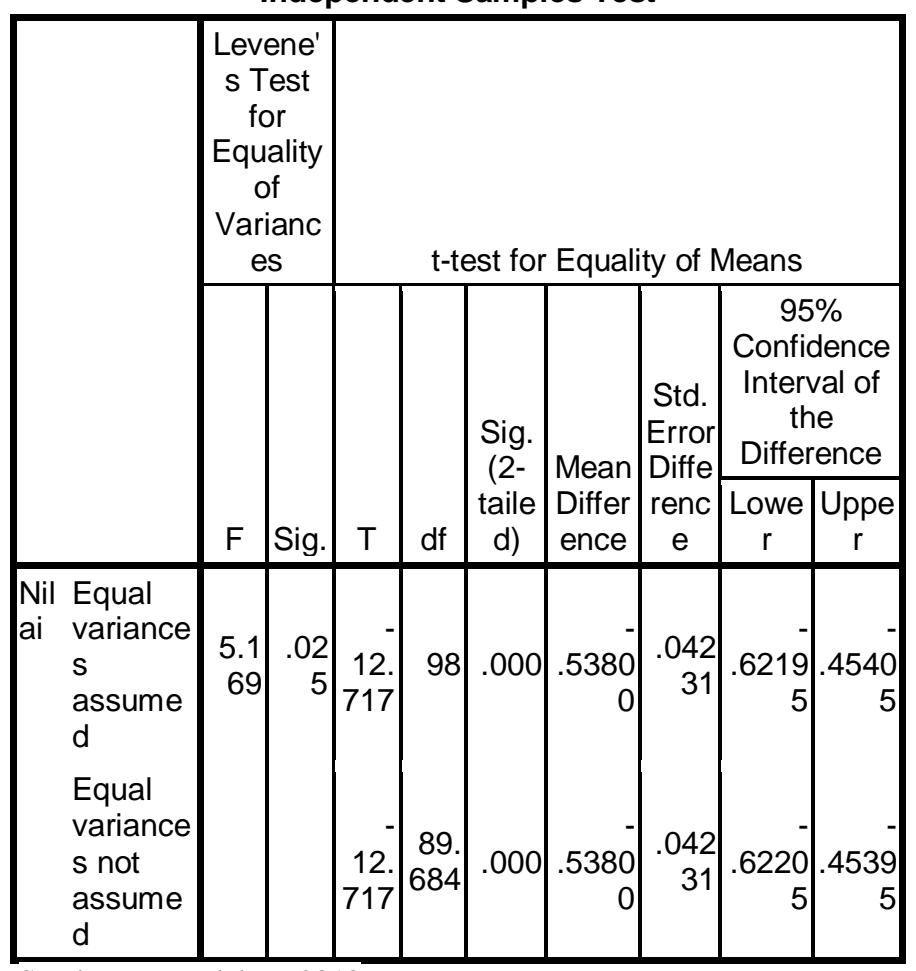

Sumber: Data olahan, 2018

Pada tabel 5 diatas diperoleh nilai sig pada uji f (Levene's Test For Equality Of Varians) $0.025<0.05$ maka varians adalah tidak sama. Dengan demikian penggunaan uji $t$ yang digunakan adalah Equal Variance Not Assumed.

Perbandingan pendapatan buruh harian tetap dan buruh harian lepas dihitung dengan menggunakan analisis perbandingan rata-rata 2 sampel. Hasil analisis dapat dilihat sebagai berikut:

Tabel 6

Hasil Uji Beda Pendapatan Buruh Harian Tetap Dengan Buruh Harian Lepas

\section{T-Test}

\begin{tabular}{|c|c|c|c|c|c|c|c|}
\hline \multicolumn{5}{|c|}{ Paired Differences } & & & \multirow{3}{*}{$\begin{array}{l}\text { Sig. } \\
\text { (2- } \\
\text { taile } \\
\text { d) }\end{array}$} \\
\hline \multirow[b]{2}{*}{$\begin{array}{c}\text { Mea } \\
\mathrm{n}\end{array}$} & \multirow{2}{*}{$\begin{array}{c}\text { Std. } \\
\text { Dev } \\
\text { atio } \\
n\end{array}$} & \multirow{2}{*}{$\begin{array}{l}\text { Std. } \\
\text { Error } \\
\text { Mean }\end{array}$} & \multicolumn{2}{|c|}{$\begin{array}{c}95 \% \\
\text { Confidence } \\
\text { Interval of } \\
\text { the } \\
\text { Difference }\end{array}$} & & & \\
\hline & & & $\begin{array}{c}\text { Lowe } \\
r\end{array}$ & Upper & $\mathrm{t}$ & $d$ & \\
\hline
\end{tabular}

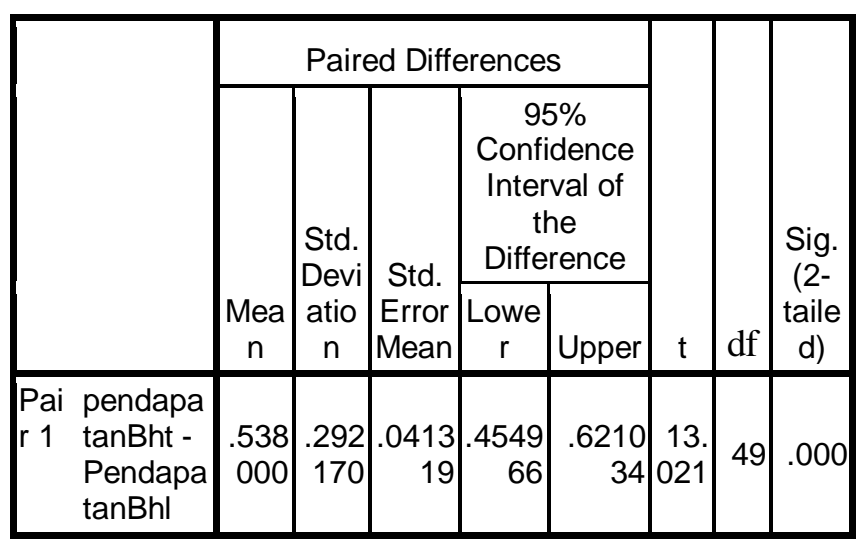

Sumber: Data Diolah, 2018

Berdasarkan hasil uji beda (uji t) diketahui nilai t-hitung sebesar 13.021 dengan probabilitas sebesar 0.000. oleh karna nilai t-hitung 13.021> 1.677 dengan probabilitas $0.000<0.05$. maka menerima Ha dan menolak Ho yang berarti bahwa terdapat perbedaan pendapatan buruh harian tetap dengan pendapatan buruh harian lepas, selisih pendapatan buruh harian tetap dengan buruh harian lepas adalah sebesar Rp. 538.000. Pendapatan buruh harian tetap sebesar Rp. 2.190.000 dan pendapatan buruh harian lepas sebesar Rp. 1.652.000. hasil ini menunjukkan pendapatan harian tetap lebih besar dibandingkan pendapatan buruh harian lepas.

\section{Tabel 7}

\section{Hasil Uji Beda Tingkat Kesejahteraan Keluarga Buruh Harian Tetap Dengan Buruh Harian Lepas}

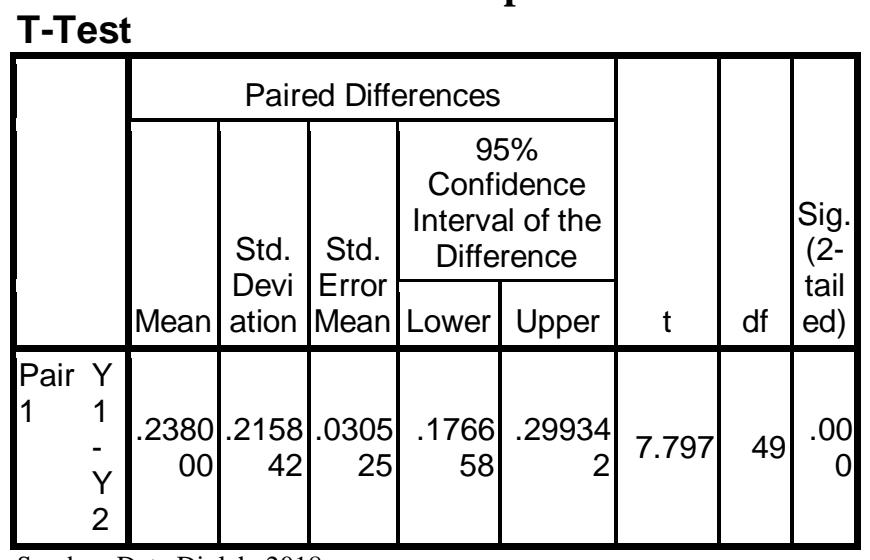

Sumber: Data Diolah, 2018

Berdasarkan hasil uji beda (uji t) diketahui nilai t-hitung sebesar 7.797 dengan probabilitas sebesar 0.000. oleh karna nilai t-hitung 7.797> 1.677 dengan probabilitas $0.000<0.05$. maka menerima Ha dan menolak Ho yang berarti bahwa terdapat perbedaan tingkat kesejahteraan keluarga buruh harian tetap dengan kesejahteraan keluarga buruh harian lepas, dimana selisih tingkat kesejahteraan keluarga buruh harian tetap dengan buruh harian lepas sebesar 2.38. 
Tabel 8

Hasil Regresi Dari Pengaruh Pendapatan

Buruh Harian Tetap Terhadap Kesejahteraan

Keluarga Buruh Perkebunan Kelapa Sawit

Di Kota Subulussalam

Two-stage Least Squares Analysis

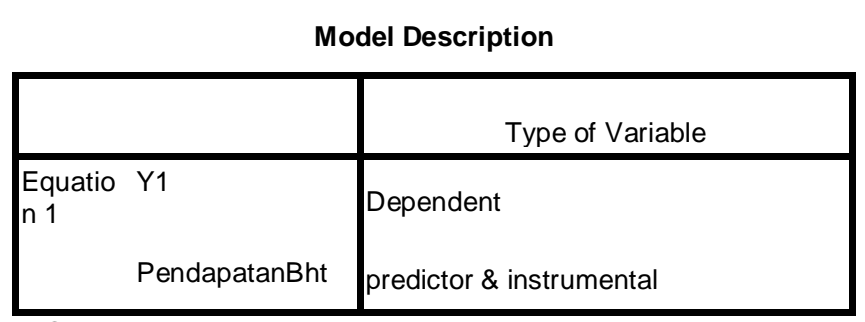

MOD_3
Tabel 9

Hasil Regresi Dari Pengaruh Pendapatan Buruh Harian Lepas Terhadap Kesejahteraan

Keluarga Buruh Perkebunan Kelapa Sawit Di Kota Subulussalam

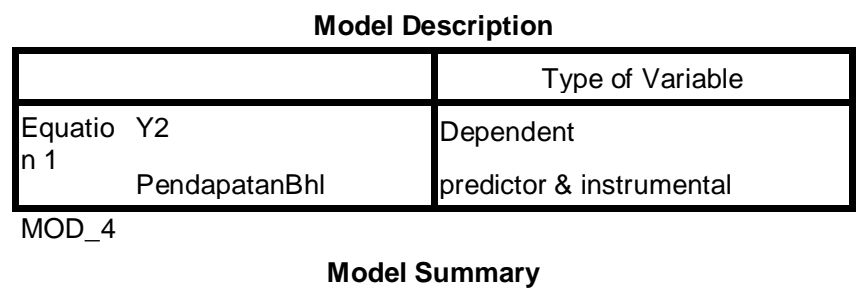

\begin{tabular}{|ll|r|}
\hline Equatio & Multiple R & .466 \\
n 1 & R Square & .217 \\
& Adjusted R Square & .201 \\
Std. Error of the & .147 \\
Estimate & .147 \\
\hline
\end{tabular}

\begin{tabular}{|ll|r|}
\hline $\begin{array}{l}\text { Equatio } \\
\text { n 1 }\end{array}$ & Multiple R & .516 \\
& R Square & .267 \\
& Adjusted R Square \\
& \\
Std. Error of the & .251 \\
Estimate & .195 \\
\hline
\end{tabular}

\begin{tabular}{|c|c|c|c|}
\hline & \multicolumn{3}{|c|}{ ANOVA } \\
\hline & Sum of Squares & Df & Mean Square \\
\hline $\begin{array}{ll}\text { Equatio } & \text { Regres } \\
\text { n } 1 & \text { sion } \\
& \text { Residua } \\
& \text { I } \\
& \text { Total }\end{array}$ & $\begin{array}{c}.661 \\
1.819 \\
2.480\end{array}$ & $\begin{array}{r}1 \\
48 \\
49\end{array}$ & \\
\hline
\end{tabular}

\begin{tabular}{|c|c|c|c|}
\hline & \multicolumn{2}{|c|}{$\begin{array}{l}\text { Unstandardized } \\
\text { Coefficients }\end{array}$} & \multirow[b]{2}{*}{ Beta } \\
\hline & B & Std. Error & \\
\hline $\begin{array}{ll}\text { Equatio (Consta } \\
\begin{array}{ll}\text { n } 1 & \text { nt) } \\
& \text { Pendap } \\
& \text { atanBht }\end{array}\end{array}$ & $\begin{array}{l}.597 \\
.481\end{array}$ & $\begin{array}{l}.254 \\
.115\end{array}$ & \\
\hline
\end{tabular}

Sumber: Data Diolah, 2018

Dari hasil perhitungan statistik memalui program SPSS hasilnya dapat dilihat pada tabel 8 di atas, maka diperoleh persamaan hasil regresi sederhananya sebagai berikut :

$$
\mathrm{Y}_{1}=0.597+0.481 \mathrm{X}_{1}
$$

Dari formulasi model diatas menunjukan bahwa nilai variabel konstanta mempunyai koefisien sebesar 0.597 yang berarti jika variabel pendapatan buruh harian tetap dianggap konstan, maka kesejahteraan keluarga buruh perkebunan kelapa sawit juga akan konstan sebesar 0.597. Koefisien pendapatan buruh harian tetap adalah sebesar 0.481 yang berarti bahwa apabila pendapatan buruh harian meningkat sebesar Rp. 1 maka kesejahteraan keluarga buruh perkebunan kelapa sawit juga akan meningkat sebesar 0.481 rupiah. 
Uji Asumsi Klasik

Uji Normalitas

Tabel 10

Uji Kolmogorov-Smirnov (K-S)

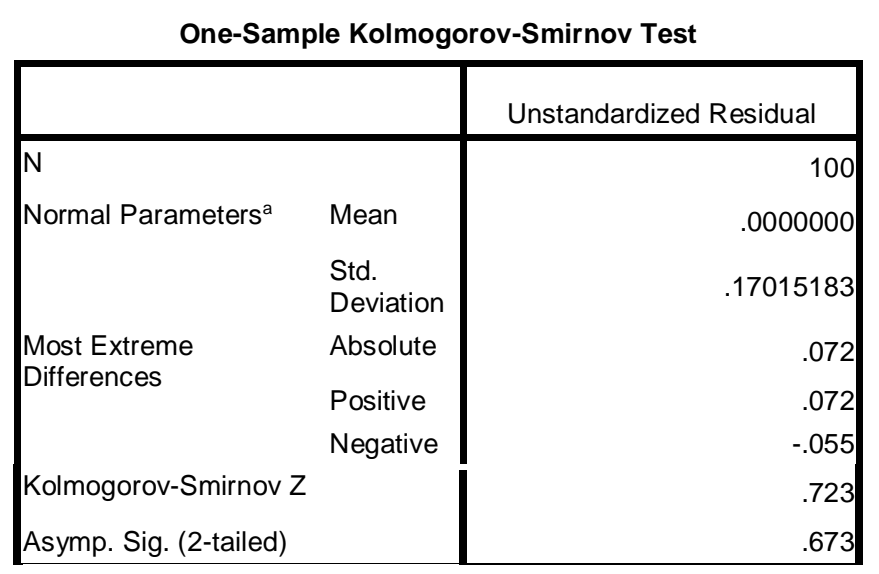

a. Test distribution is Normal.

Dari tabel 10 uji normalitas dengan cara analisis statistik diketahui bahwa probabilitas nilai Z $0.673>0.05$ atau tidak signifikan. Maka secara statistik menyatakan Ho diterima yang berarti bahwa data telah terdistribusi normal.

\section{Uji Heterokedastisitas}

Tabel 11

Uji Heterokedastisitas

Coefficients $^{a}$

\begin{tabular}{|c|c|c|c|c|c|}
\hline \multirow[b]{2}{*}{ Model } & \multicolumn{2}{|c|}{$\begin{array}{l}\text { Unstandardized } \\
\text { Coefficients }\end{array}$} & \multirow{2}{*}{\begin{tabular}{|c}
$\begin{array}{c}\text { Standar } \\
\text { dized } \\
\text { Coefficie } \\
\text { nts }\end{array}$ \\
Beta \\
\end{tabular}} & \multirow[b]{2}{*}{$\mathrm{t}$} & \multirow[b]{2}{*}{ Sig. } \\
\hline & B & $\begin{array}{l}\text { Std. } \\
\text { Error }\end{array}$ & & & \\
\hline $1 \quad$ (Constant) & -5.641 & 1.407 & & -4.011 & .000 \\
\hline $\begin{array}{l}\text { pendapata } \\
\mathrm{n} \text { buruh }\end{array}$ & .571 & .709 & .115 & .805 & .425 \\
\hline
\end{tabular}

a. Dependent Variable:

LnRES_2

Sumber: Data Diolah, 2018

Dari hasil output di atas tampak bahwa nilai probabilitas dari hasil estimasi Uji Park (Park Test) adalah $0.425>0.05$ maka dapat disimpulkan bahwa nilai tes ini tidak signifikan statistik yang berarti bahwa data empiris yang diestimasi tidak terdapat heteroskedastisitas.

\section{Pengujian Hipotesis}

\section{Uji Signifikansi Parameter Individual (Uji t)}

\section{Tabel 12}

Parsial (Uji t)

\begin{tabular}{|c|c|c|c|c|c|}
\hline \multicolumn{5}{|c|}{ Variabel Dependen Kesejahteraan Keluarga Buruh } \\
\hline Variabel & $\begin{array}{c}\text { t- } \\
\text { statisti } \\
k\end{array}$ & $\begin{array}{c}\text { tabe } \\
\text { tabe }\end{array}$ & $\begin{array}{c}\text { Pro } \\
\text { b }\end{array}$ & $\begin{array}{c}\text { Keterang } \\
\text { an }\end{array}$ & $\begin{array}{c}\text { Hipotes } \\
\text { is }\end{array}$ \\
\hline
\end{tabular}

\begin{tabular}{|l|c|c|c|l|c|}
\hline $\begin{array}{c}\text { Pendapat } \\
\text { an BHT }\end{array}$ & 4.177 & & 0.00 & Signifikan & $\begin{array}{c}\text { Diterim } \\
\text { a }\end{array}$ \\
\cline { 1 - 2 } $\begin{array}{c}\text { Pendapat } \\
\text { an BHL }\end{array}$ & 3.645 & 8 & $\begin{array}{c}0.00 \\
1\end{array}$ & Signifikan & $\begin{array}{c}\text { Diterim } \\
\text { a }\end{array}$ \\
\hline
\end{tabular}

Berdasarkan hasil tabel di atas pengujian sebagaiman yang di tunjukkan pada tabel 12 maka dapat dilihat bahwa pendapatan buruh harian tetap memiliki nilai $\mathrm{t}$-hitung4.177 dengan nilai signifikansi 0.000 sementara itu t-tabel dengan (df) $=\mathrm{n}-\mathrm{k} \quad(50-3=47)$ pada $\alpha 0,05$ di peroleh nilai sebesar 1,678 maka t-hitung $>\mathrm{t}$-tabel yaitu 4.177> 1,678 dengan nilai signifikansi $0.000<0,05$ maka keputusan adalah hipotesis menolak $\mathrm{H}_{\mathrm{O}}$ dan menerima Ha, yang berarti bahwa secara parsial pendapatan buruh harian tetap berpengaruh secara signifikan terhadap kesejahteraan keluarga buruh perkebunan kelapa sawit di kota subulussalam.

Dan dapat dilihat juga pendapatan buruh harian lepas memiliki t-hitung 3.645 dengan nilai signifikansi 0.001 sementara itu $\mathrm{t}$-tabel dengan (df) $=\mathrm{n}-\mathrm{k}(50-3=47)$ pada $\alpha 0,05$ di peroleh nilai sebesar 1,678 maka $t$-hitung $>t$-tabel yaitu 3.645 $>1,678$ dengan nilai signifikansi $0.001<0,05$ maka keputusan adalah hipotesis menolak $\mathrm{H}_{\mathrm{O}}$ dan menerima Ha, yang berarti bahwa secara parsial pendapatan buruh harian lepas berpengaruh secara signifikan terhadap kesejahteraan keluarga buruh perkebunan kelapa sawit di kota subulussalam.

\section{Koefisien Determinasi $\left(\mathbf{R}^{\mathbf{2}}\right)$}

Perhitungan ini dilakukan untuk mengukur seberapa jauh kemampuan model dalam menerangkan variasi variabel dependen.

Tabel 13

\section{Hasil Uji Adjusted R-squared}

\begin{tabular}{|c|}
\hline Adjusted R-squared \\
\hline 0.251 \\
\hline 0.201 \\
\hline
\end{tabular}

Berdasarkan tabel 4.20 di atas diketahui bahwa nilai koefisien determinasi $\left(\mathrm{R}^{2}\right)$ adalah sebesar:

1. Adjusted R-squared $=0.251$ atau $25.10 \%$, artinya pengaruh pendapatan buruh harian tetap (BHT)terhadap kesejahteraan keluarga buruh adalah sebesar 0.251 atau $25.1 \%$ dan di pengaruhi oleh variabel lain yang tidak dimasukkan dalam model penelitian ini sebesar 0.749 atau $74.9 \%$.

2. Adjusted R-squared $=0.201$ atau $20.10 \%$, artinya pengaruh pendapatan buruh harian 
lepas (BHL)terhadap kesejahteraan keluarga buruhadalah sebesar 0.201atau $20.1 \%$ dan di pengaruhi oleh variabel lain yang tidak dimasukkan dalam model penelitian ini sebesar 0.799 atau $79.9 \%$.

\section{Pembahasan \\ Perbandingan Pendapatan Buruh Harian Tetap Dan Buruh Harian Lepas}

Berdasarkan hasil uji beda (uji t) diketahui nilai thitung sebesar 13.021 dengan probabilitas sebesar 0.000. oleh karna nilai t-hitung $13.021>1.677$ dengan probabilitas $0.000<0.05$. maka menerima Ha dan menolak Ho yang berarti bahwa terdapat perbedaan pendapatan buruh harian tetap dengan pendapatan buruh harian lepas, selisih pendapatan buruh harian tetap dengan buruh harian lepas adalah sebesar Rp. 538.000. Pendapatan buruh harian tetap sebesar Rp. 2.190.000 dan pendapatan buruh harian lepas sebesar Rp. 1.652.000. hasil ini menunjukkan pendapatan harian tetap lebih besar dibandingkan pendapatan buruh harian lepas.

\section{Perbandingan Tingkat Kesejahteraan Keluarga Buruh Harian Tetap Dengan Buruh Harian Lepas}

Berdasarkan hasil uji beda (uji t) diketahui nilai t-hitung sebesar 7.797 dengan probabilitas sebesar 0.000. oleh karna nilai t-hitung $7.797>$ 1.677 dengan probabilitas $0.000<0.05$. maka menerima Ha dan menolak Ho yang berarti bahwa terdapat perbedaan tingkat kesejahteraan keluarga buruh harian tetap dengan kesejahteraan keluarga buruh harian lepas, dimana selisih tingkat kesejahteraan keluarga buruh harian tetap dengan buruh harian lepas sebesar 2.38. Kesejahteraan keluarga buruh harian tetap sebesar 16.50 dan kesejahteraan keluarga buruh harian lepas sebesar 14.12. hasil ini menunjukkan keluarga buruh harian tetap lebih sejahtera dibandingkan keluarga buruh harian lepas.

\section{Pengaruh Pendapatan Buruh Harian Tetap Terhadap Kesejahteraan Keluarga Buruh}

Hasil pengujian bahwa pendapatan buruh harian tetap berpengaruh secara signifikan terhadap kesejahteraan keluarga buruh perkebunan kelapa sawit di kota subulussalam. Hal ini ditunjukan dengan nilai t-hitung4.177 dengan nilai signifikansi 0.000 sementara itu $\mathrm{t}$-tabel dengan (df) $=\mathrm{n}-\mathrm{k} \quad(50-3=47)$ pada $\alpha 0,05$ diperoleh nilai sebesar 1,678 maka t-hitung $>t$-tabel yaitu 4.177> 1,678. Apabila pendapatan buruh harian tetap bertambah Rp. 1 maka kesejahteraan keluarga buruh perkebunan kelapa sawit di kota subulussalam juga akan meningkat sebesar 0.481.

\section{Pengaruh Pendapatan Buruh Harian Lepas Terhadap Kesejahteraan Keluarga Buruh}

Hasil pengujian bahwa pendapatan buruh harian lepas berpengaruh secara signifikan terhadap kesejahteraan keluarga buruh perkebunan kelapa sawit di kota subulussalam. Hal ini ditunjukan dengan nilaint-hitung 3.645 dengan nilai signifikansi 0.001 sementara itu $\mathrm{t}$-tabel dengan (df) $=\mathrm{n}-\mathrm{k}(50-3=47)$ pada $\alpha 0,05$ di peroleh nilai sebesar 1,678 maka $t$-hitung $>\mathrm{t}$-tabel yaitu 3.645> 1,678. Apabila pendapatan buruh harian lepas bertambah Rp. 1 makakesejahteraan keluarga buruh perkebunan kelapa sawit di kota subulussalam juga akan meningkat sebesar 0.435.

\section{PENUTUP}

\section{Kesimpulan}

1. Berdasarkanhasil uji beda (uji t) diketahui nilai $\mathrm{t}$ hitung 13.021> 1.677 denganprobabilitas $0.000<0.05$. hal ini menunjukkan adanya perbedaan tingkat pedapatan buruh harian tetap (BHT) dengan buruh harian lepas (BHL). Adapun rata-rata pendapatan buruh harian tetap (BHT) sebesar Rp. 2.190.000 dan pendapatan buruh harian lepas (BHL) sebesar Rp. 1.652.000

2. Berdasarkanhasil uji beda (uji t) diketahui nilai $\mathrm{t}$ hitung 7.797> 1.677 dengan probabilitas $0.000<0.05$. hasil ini menunjukkan adanya perbedaaan tingkat kesejahteraan keluarga buruh harian tetap (BHT) dengan tingkat kesejahteraan keluarga buruh harian lepas (BHL). Dimana keluarga buruh harian tetap (BHT) lebih sejahtera dibandingkan keluarga buruh harian lepas (BHL).

3. Hasil uji regresi linier sederhana dengan metode 2sls menyatakan bahwa variabel pendapatan buruh harian tetap (BHT) dan buruh harian lepas (BHL) berpengaruh positif dan signifikan terhadap kesejahteraan keluarga buruh perkebunan kelapa sawit di kota subulussalam.

4. Dari hasil uji asumsi klasik yang dilakukan, baik uji normalitas maupun uji heterokedastisitas pada data yang digunakan sudah terbebas dari uji asumsi klasik. 


\section{Saran}

Berdasarkan hasil penelitian dan kesimpulan di atas, maka penulis memberikan beberapa saran sebagai berikut:

1. Berdasarkan penelitian bahwa pendapatan dan kesejahteraan keluarga buruh harian termasuk dalam kategori sedang. Dengan adanya hal tersebut maka sebaiknya pihak kesatuan perkebunan dari pemerintah dan kelompok pengusaha perkebunan memberikan pelatihan keterampilan yang dapat dijadikan sebagai pekerjaan tambahan dalam rangka meningkatkan perekonomian keluarga.

2. Bagi peneliti selanjutnya yang ingin meneliti tentang perbandingan pendapatan buruh dan pengaruhnya terhadap kesejahteraan keluarga buruh. Ada baiknya menambah variabel-variabel lain untuk diteliti, karena sebenarnya ada beberapa variabel yang sangat mempengaruhi kesejahteraan keluarga.

\section{DAFTAR PUSTAKA}

Ghozali, I. (2012). Aplikasi Analisis Multivariate Dengan Program Ibm Spss 19. Universitas Diponegoro.

Marbum, B. (2003). Kamus Manajemen. Pustaka Sinar Harapan.

Nitisusastro, M. (2013). Perilaku Konsumen Dalam Prespektif Kewirausahaan. Alfabeta Bandung.

Nurachmad, M. (2009). Cara Menghitung Upah Pokok, Uang Lembur, Pesangon, \& Dana Pensiun untuk Pegawai dan Perusahaan.Jakarta: Visimedia.

Purwana, A. E. (2014). Kesejahteraan dalam Perspektif Ekonomi Islam. Ponorogo: STAIN.

Puspitawati, H. (2013). Ketahanan dan Kesejahteraan Keluarga. Institut Pertanian Bogor.

Reksoprayitno. (2009). Sistem Ekonomi dan Demokrasi Ekonomi.Jakarta: Bina Grafika. Sugiyono. (2012). Statistik Untuk Penelitian. Bandung: Alfabeta.

Sugiyono. (2014). Metode Penelitian Kuantitatif. Alfabeta Bandung.

Suharsimi, A. (2002). Prosedur Penelitian Suatu

Pendekatan Praktek. Jakarta. PT. Rineka Cipta.

Sukirno, S. (2006). Teori Pengantar Mikro

Ekonomi. Rajagrafindo Persada, Jakarta, .
Supranto, J. (2003). Metode penelitian hukum dan statistik. Universitas Indonesia.

Undang-Undang Republik Indonesia No. 52 Tahun 2009 Tentang Perkembangan Kependudukan dan Pembangunan Keluarga. Jakarta 